\title{
ANALISIS FAKTOR-FAKTOR YANG MEMPENGARUHI IMPOR BERAS DI INDONESIA
}

\author{
Yona Namira, Iskandar Andi Nuhung* dan Mudatsir Najamuddin
}

\begin{abstract}
ABSTRAK
Penelitian ini bertujuan untuk 1) mengidentifikasi faktor-faktor yang mempengaruhi impor beras di Indonesia 2) menganalisis pengaruh faktor-faktor ini impor beras di Indonesia. Data yang digunakan dalam penelitian ini adalah data time series 1994-2013 dari Badan Pusat Statistik (BPS), Departemen Pertanian, Departemen Perdagangan, Badan Urusan Logistik (Bulog), dan Bank Indonesia. Regresi linier berganda melalui software SPSS versi 21 digunakan untuk menganalisis data. Hasil uji secara bersama-sama menunjukkan variabel produksi, konsumsi, stok beras, harga beras dalam negeri, harga beras internasional dan nilai tukar rupiah terhadap dolar AS mempengaruhi impor beras di Indonesia.
\end{abstract}

Kata kunci: impor, beras, pengaruh, regresi linear

\begin{abstract}
This study aims to 1) identify factors that affect the import of rice in Indonesia 2) analyze the influence of these factors on imports of rice in Indonesia. The data used in this research are time series data from 1994 to 2013 from the Central Statistics Agency (BPS), the Ministry of Agriculture, Ministry of Commerce, National Logistics Agency (Bulog), and Bank Indonesia. Multiple linear regression through SPSS software version 21 was employed to analyze the data. The test results together indicated the variables of productions, consumptions, stocks of rice, domestic rice prices, international rice prices and the rupiah against the US dollar affect the imports of rice in Indonesia.
\end{abstract}

Keywords: import, rice, influence, linear regression

\section{PENDAHULUAN}

Padi (Oryza sativa L.) hingga kini masih dianggap sebagai komoditas strategis dan mendapat prioritas yang tinggi dalam program pembangunan nasional. Hal tersebut disebabkan padi/beras merupakan kebutuhan pangan pokok bagi lebih dari $90 \%$ penduduk Indonesia (Departemen Pertanian, 
2012:3). Konsumsi beras di Indonesia selain untuk kebutuhan rumah tangga juga dipergunakan sebagai bahan baku seperti industri pengolahan tepung beras dan bahan makanan lainnya (Wibowo, 2000:14).

Produksi beras dalam negeri diharapkan dapat memenuhi semua kebutuhan masyarakat Indonesia karena dengan berhasilnya pemenuhan beras dalam negeri berarti pemerintah tidak memerlukan tindakan untuk mengimpor beras dari negara lain. Berikut perkembangan produksi dan konsumsi beras di Indonesia disajikan pada Tabel 1.

Tabel 1. Perkembangan Produksi dan Konsumsi Beras (Ton) di Indonesia Tahun

2004-2013

\begin{tabular}{|l|l|l|}
\hline Tahun & Produksi & Konsumsi \\
\hline 2004 & 34.183 .912 & 36.054 .000 \\
\hline 2005 & 34.223 .494 & 35.902 .000 \\
\hline 2006 & 34.415 .520 & 35.676 .000 \\
\hline 2007 & 36.123 .499 & 36.926 .000 \\
\hline 2008 & 38.125 .985 & 37.943 .000 \\
\hline 2009 & 40.403 .864 & 38.177 .000 \\
\hline 2010 & 41.702 .898 & 37.796 .000 \\
\hline 2011 & 41.255 .882 & 37.180 .000 \\
\hline 2012 & 43.325 .813 & 38.859 .000 \\
\hline 2013 & 44.720 .889 & 39.716 .000 \\
\hline
\end{tabular}

Sumber: BPS dan Kementerian Pertanian, 2014 (diolah)

Tabel 1 menunjukkan
perkembangan produksi dan
konsumsi beras di Indonesia
cenderung berfluktuasi. Pada tahun
2004 hingga 2007 jumlah konsumsi
beras berada diatas jumlah produksi,
artinya bahwa produksi beras dalam
negeri belum mampu mencukupi
kebutuhan beras dalam negeri. Tetapi
dari tahun 2008 hingga 2013 produksi

beras dalam negeri lebih tinggi dari konsumsi atau surplus sebesar ratarata 3,3 juta ton. Kenyataannya, meskipun mengalami surplus, Indonesia masih bergantung pada impor beras dari negara lain. Hal tersebut dilakukan pemerintah untuk menjaga cadangan persediaan stok beras nasional. Berikut data perkembangan impor beras dalam 20 tahun terakhir disajikan pada gambar 1 .

Gambar 1. Volume Impor Beras Tahun 1994-2013

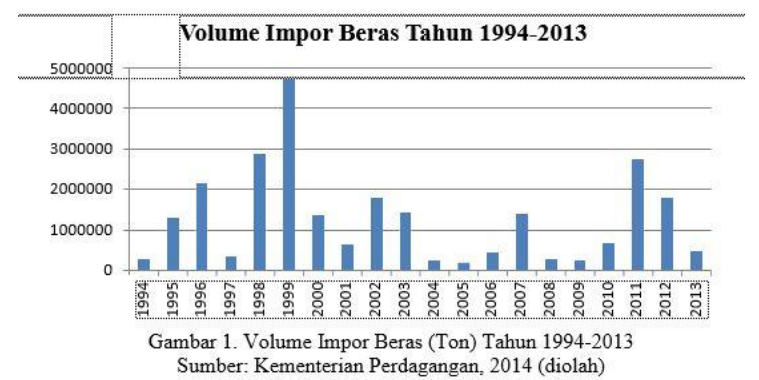

Gambar 1 menunjukkan perkembangan impor beras di Indonesia dari tahun 1994 sampai 2013 mengalami fluktuasi. Impor beras tertinggi terjadi pada tahun 1999 yaitu sebesar 4,7 juta ton. Menurut Sawit (2000:229) hal ini disebabkan oleh pihak importir swasta yang memiliki peran sangat besar dan dipengaruhi oleh perkiraan para pedagang bahwa adanya kebijakan impor beras yang baru pada tahun 2000 yaitu penetapan tarif impor beras yang besarnya Rp. 430/kg pada awal Januari 2000.

Menurut Mankiw dkk (2013:185) banyak faktor yang mempengaruhi impor diantaranya adalah harga barang dalam negeri dan luar negeri dan nilai tukar mata uang asing. Berdasarkan hal diatas, peneliti ingin melakukan penelitian tentang "Analisis Faktor-Faktor Yang Mempengaruhi Impor Beras di Indonesia." 


\section{Perumusan Masalah}

1. Apa saja faktor-faktor yang mempengaruhi impor beras di Indonesia?

2. Bagaimana pengaruh faktorfaktor tersebut terhadap impor beras di Indonesia?

\section{METODE PENELITIAN}

\section{Lokasi danWaktuPenelitian}

Penelitian ini dilakukan dengan cara pengambilan data pada beberapa lembaga pemerintah seperti Kementerian Pertanian, Kementerian Perdagangan, Badan Pusat Statistik (BPS), Badan Urusan Logistik (BULOG), dan Bank Indonesia. Penelitian ini dilaksanakan selama 6 bulan, yaitu awal bulan Agustus2014 hingga akhir Januari 2015. Jadwal penelitian disajikan pada lampiran 1 .

\section{Jenis dan Sumber Data}

Jenis data yang digunakan dalam penelitian ini merupakan data sekunder. Data sekunder adalah data yang diperoleh tidak langsung dari objek penelitiannya, melainkan dari sumber lain, baik lisan maupun tulisan (Nazir, 2011:50). Menurut Teguh (2005:121) data sekunder adalah jenis data yang diperoleh dan digali melalui hasil pengolahan pihak kedua dari hasil penelitian lapangannya, baik berupa data kualitatif maupun data kuantitatif.

Sumber data yang dipakai untuk mendapatkan data-data tersebut yaitu Badan Ketahanan Pangan Kementerian Pertanian untuk data konsumsi beras, Badan Pusat Statistik (BPS) untuk data produksi beras, Kementerian Pertanian untuk data harga beras internasional, Kementerian Perdagangan untuk data impor beras dan harga beras domestik, Badan Urusan Logistik (BULOG) untuk data stok beras, dan Bank Indonesia untuk data nilai tukar rupiah terhadap dollar Amerika.

\section{Metode Pengumpulan Data}

Metode pengumpulan data adalah cara-cara yang dapat digunakan dalam peneliti untuk mengumpulkan data. Penelitian ini menggunakan data sekunder dengan data deret waktu (time series) pada skala tahunan dari tahun 1994 hingga tahun 2013. Metode yang digunakan dalam pengumpulan data pada penelitian ini yaitu teknik pengumpulan data dengan cara mengkaji dan memahami sumbersumber data yang dibutuhkan dalam penelitian ini. Mengunjungi lembaga- lembaga yang terkait dalam penelitian ini, seperti BPS, BULOG, Kementerian Perdagangan, dan Kementerian Pertanian. Pengumpulan data dalam penelitian ini juga menggunakan media internet untuk pengambilan data nilai tukar rupiah terhadap dollar Amerika pada website Bank Indonesia yaitu www.bi.go.id.

\section{MetodePengolahan danAnalisis Data}

Metode pengolahan dan analisis data dalam penelitian ini menggunakan regresi linear berganda. Selain itu juga digunakan uji asumsi klasik dan uji hipotesis. Regresi digunakan untuk mengetahui pengaruh variabel bebas (produksi, konsumsi, stok beras, harga beras domestik, harga beras internasional, dan nilai tukar rupiah terhadap dollar Ameika) terhadap variabel terikat yaitu impor beras. 


\begin{abstract}
Data yang diperoleh dalam penelitian ini dianalisis secara kuantitatif. Pengolahan data pada variabel-variabel penelitian ini menggunakan bantuan Miscrosoft Office Excel 2007 dan Statistical Product and Service Solutions (SPSS) versi 21.
\end{abstract}

\section{Model Persamaan Regresi}

Menurut Widarjono (2010:9) regresi adalah studi bagaimana satu variabel yaitu variabel dependen dipengaruhi oleh satu atau lebih dari variabel lain yaitu variabel independen dengan tujuan untuk mengestimasi dan atau memprediksi nilai rata-rata variabel dependen didasarkan pada nilai variabel independen yang diketahui. Secara singkat, tujuan utama regresi adalah untuk memprediksi nilai variabel dependen berdasarkan satu atau lebih variabel independen.

Analisis yang digunakan dalam penelitian ini adalah analisis regresi linear berganda (multiple regression). Analisis ini bertujuan untuk mengetahui pengaruh variabel independennya terhadap variabel dependen (Ghozali, 2011:95).

Persamaan analisis regresi linear berganda penelitian ini dirumuskan dalam persamaan sebagai berikut:

$$
\mathrm{Y}
$$

$$
=a+b_{1} X_{1}+b_{2} X_{2}+b_{3} X_{3}+b_{4} X_{4}+b_{5} X_{5}+b_{6}
$$$$
\mathrm{X}_{6}+\mathrm{e}
$$

Di mana:

$\mathrm{Y} \quad=$ Impor Beras di Indonesia

a $\quad=$ Konstanta

b1 ...b6 = Koefisien regresi dari setiap variabel bebas

$$
\begin{array}{ll}
\text { X1 } & =\text { Produksi Beras } \\
\text { X2 } & =\text { Konsumsi Beras } \\
\text { X3 } & =\text { Stok Beras } \\
\text { X4 } & =\text { Harga Beras Domestik } \\
\text { X5 } & =\text { Harga Beras Internasional }
\end{array}
$$

X6 = Nilai Tukar Rupiah Terhadap

Dollar Amerika

e $\quad=$ standard error

\section{Uji AsumsiKlasik}

Untuk mengetahui pengaruh perubahan variabel independen terhadap dependen baik secara parsial maupun simultan, maka digunakan regresi linear berganda (Multiple Regression) dan alpha yang digunakan adalah $5 \%$. Sebelum dilakukan pengujian dengan regresi berganda, variabel-variabel penelitian diuji dengan asumsi klasik atau bisa dikenal dengan uji BLUE (Best Linear Unbiased Estimate) yaitu data terdistribusi normal (uji normalitas), tidak terjadinya heteroskedastisitas, tidak terjadinya multikolinearitas, dan tidak terjadinya autokorelasi (Ghozali, 2011 : 103). Uji asumsi klasik terdiri dari pengujianpengujian sebagai berikut:

\section{Uji Normalitas}

Uji normalitas bertujuan untuk menguji apakah dalam model regresi, variabel pengganggu atau residual memiliki distribusi normal. Seperti diketahui bahwa uji $t$ dan uji $F$ mengasumsikan bahwa nilai residual mengikuti distribusi normal. Jika asumsi ini dilanggar, maka uji statistik menjadi tidak valid. Salah satu cara yang dapat digunakan untuk menguji normalitas model regresi adalah melihat penyebaran data (titik) pada sumbu diagonal dari grafik Normal Probability Plot. Jika data menyebar di sekitar garis diagonal dan mengikuti arah garis diagonalnya, maka model regresi memenuhi asumsi normalitasnya (Ghozali 2011 : 160).

\section{Uji Heteroskedastisitas}




\begin{abstract}
Uji Heteroskedastisitas bertujuan untuk menguji apakah dalam model regresi terjadi ketidaksamaan varian dari residual satu pengamatan ke pengamatan yang lain. Jika varian dari residual satu pengamatan ke pengamatan yang lain tetap, maka disebut homoskedatisitas dan jika berbeda disebut heteroskedastisitas. Model regresi yang baik yaitu jika terjadi homoskedatisitas atau tidak terjadi heteroskedastisitas (Ghozali, 2011 : 139).

Salah satu cara yang dapat digunakan untuk mengujui heteroskedastisitas adalah dengan melihat penyebaran data (titik) pada grafik Scatterplot. Jika titik- titik tidak membentuk pola tertentu dan menyebar didaerah positif dan negatif, maka tidak terjadi heteroskedastisitas pada model regresi (Ghozali, 2011: 139).
\end{abstract}

\section{Uji Multikolinearitas}

Multikolinearitas

(multicollinearity) merupakan hubungan linear antara variabel independen di dalam regresi berganda (Widarjono, 2010:75). Uji Multikolinearitas ini bertujuan untuk menguji apakah dalam model regresi ditemukan adanya korelasi antar variabel bebas (independen). Model regresi yang baik seharusnya tidak terjadi korelasi di antara variabel independen. Untuk mendeteksi ada tidaknya multikolinearitas dalam model regresi dapat dilihat dari tolerance value atau Variance Inflation Factor (VIF). Ukuran tersebut menunjukkan setiap variabel independen manakah yang dijelaskan oleh variabel independen lainnya (Ghozali, 2011 : 105).

Dalam pengertian sederhana setiap variabel independen menjadi variabel dependen (terikat) dan diregresi terhadap variabel independen lainnya. Tolerance mengukur variabilitas variabel independen yang terpilih yang tidak dijelaskan oleh variabel independen lainnya. Jadi nilai tolerance yang rendah sama dengan nilai VIF yang tinggi (Ghozali, 2011 : 105-106). Nilai cutoff yang umum dipakai adalah :

1) Jika nilai tolerance $>10$ persen dan nilai VIF $<10$, maka dapat disimpulkan bahwa tidak ada multikolinearitas antar variabel independen dalam model regresi.

2) Jika nilai tolerance $<10$ persen dan nilai VIF > 10, maka dapat disimpulkan bahwa ada multikolinearitas antar variabel independen dalam model regresi.

\section{Uji Autokorelasi}

Uji Autokorelasi bertujuan menguji apakah dalam model regresi linear ada korelasi antara kesalahan pengganggu pada periode $t$ dengan kesalahan pengganggu pada periode t-1 (sebelumnya). Jika terjadi korelasi, maka dinamakan ada problem autokorelasi. Autokorelasi muncul karena observasi yang berurutan sepanjang waktu berkaitan satu sama lainnya. Masalah ini timbul karena kesalahan pengganggu (residual) tidak bebas dari satu observasi ke observasi lainnya. Hal ini sering ditemukan pada data runtut waktu (time series) karena gangguan pada seseorang individu atau kelompok cenderung mempengaruhi gangguan pada individu atau kelompok yang sama pada periode berikutnya (Ghozali, 2011 : 110).

\section{Pengujian Hipotesis Uji Parsial atauUji t}


Uji Parsial atau Uji t pada dasarnya menunjukan seberapa jauh pengaruh variabel independen secara individual dalam menerangkan variasi variabel dependen (Ghozali, 2011 : 98). Uji t digunakan untuk membuktikan apakah variabel independen secara individu mempengaruhi variabel dependen. Ada dua hipotesis yang diajukan oleh setiap peneliti yaitu hipotesis nol ( $\mathrm{H} 0)$ dan hipotesis alternative (Ha) (Widarjono, 2010:25).

Uji t dapat dilakukan dengan rumus:

\section{$\mathrm{T}=\mathrm{B} /$ St. Error}

Cara melakukan uji t adalah sebagai berikut:

1. Quick look : bila jumlah degree of freedom (df) adalah 20 atau lebih, dan derajat kepekaan sebesar 5\%, maka Ha dapat diterima bila nanti t lebih besar dari 2 (dalam nilai absolute). Dengan kata lain, suatu variabel independen secara individual mempengaruhi variabel dependen.

2. Membandingkan nilai $t$ dengan titik krisis menurut tabel. Apabila nilai $\mathrm{t}$ hasil perhitungan lebih tinggi dibandingkan $\mathrm{t}$ tabel, maka H0 ditolak dan $\mathrm{Ha}$ diterima (Ghozali, 2011:98).

\section{Uji Simultan atau Uji F}

Untuk menguji hipotesis dalam penelitian ini apakah H0 diterima yang berarti secara bersama-sama variabel bebas tidak berpengaruh terhadap variabel terikat atau $\mathrm{Ha}$ diterima yang berarti secara bersamasama variabel berpengaruh terhadap variabel terikat, maka dapat digunakan uji $\mathrm{F}$ dengan rumus sebagaiberikut (Ghozali, 2011:8):

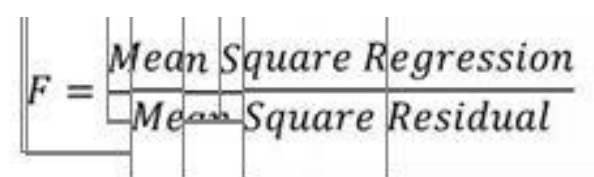

Dengan kriteria pengambilan keputusan sebagai berikut:

1. Quick look: bila nilai F lebih besar daripada 4 maka Ha dapat diterima pada derajat kepekaan 5\%. Dengan kata lain, semua variabel bebas secara serentak berpengaruh terhadap variabel terikat.

2. Membandingkan nilai $\mathrm{F}$ hasil perhitungan dengan nilai $\mathrm{F}$ menurut tabel.

Apabila nilai $\mathrm{F}$ hitung lebih besar daripada $\mathrm{F}$ tabel, maka $\mathrm{H} 0$ ditolak dan Ha diterima (Ghozali, 2011:98).

\section{Koefisien Determinasi}

Koefisien determinasi adalah salah satu nilai statistik yang dapat digunakan untuk mengetahui apakah ada hubungan pengaruh antara dua variabel.

Koefisien determinasi (R2) pada intinya mengukur seberapa jauh kemampuan suatu model dalam menerangkan variasi variabel dependennya. Nilai koefisien determinasi (R2) yang kecil berarti kemampuan variabel-variabel independen dalam menjelaskan variasi variabel dependen amat terbatas. Nilai yang mendekati satu berarti variabel-variabel independennya memberikan hampir semua informasi yang dibutuhkan untuk memprediksi variasi variabel dependen.

Hal-hal yang perlu diperhatikan mengenai koefisien determinasi adalah sebagai berikut:

1. Nilai $\mathrm{R}^{2}$ harus berkisar 0 sampai 1

2. Bila $\mathrm{R}^{2}=1$ berarti terjadi kecocokan sempurna dari 
variabel independen menjelaskan variabel dependen.

3. Bila $\mathrm{R}^{2}=0$ berarti tidak ada hubungan sama sekali antara variabel independen terhadap variabel dependen.

\section{Definisi Operasional Variabel Variabel Dependen}

Variabel dependen dalam penelitian ini adalah impor beras. Impor beras adalah kegiatan memasukkan beras ke dalam daerah pabean negara Republik Indonesia yang meliputi wilayah darat, perairan, dan ruang udara di atasnya, tempat-tempat tertentu di Zona Ekonomi Eksklusif, dan landas kontinen dalam satuan ton per tahun.

\section{Variabel Independen}

Variabel independen adalah variabel yang mempengaruhi menjadi sebab perubahannya atau timbulnya variabel terikat (dependen). Adapun variabel- variabel independen yang terdapat dalam penelitian ini yaitu:

\section{1) Produksi Beras}

Produksi beras adalah kegiatan atau proses menghasilkan, menyiapkan, mengolah, membuat, mengawetkan, mengemas, atau mengubah bentuk padi menjadi beras dalam satuan ton per tahun. Produksi beras diperoleh dari hasil perkalian antara produksi padi dengan faktor konservasi. Berdasarkan hal tersebut, maka produksi beras dapat dirumuskan sebagai berikut:

$\mathrm{PB}_{\mathrm{t}}=\mathrm{TPP}_{\mathrm{t}} * \mathrm{FK}_{\mathrm{t}}$

Di mana :

$\mathrm{PB}_{\mathrm{t}}=$ Produksi beras tahun ke- $\mathrm{t}$ (Ton)

$\mathrm{TPP}_{\mathrm{t}}=$ Total produksi padi tahun ke- $\mathrm{t}$ (Ton) $\mathrm{FK}_{\mathrm{t}} \quad=$ Faktor Konversi

2) Konsumsi Beras
Konsumsi beras adalah jumlah beras yang dimakan penduduk/seseorang dalam satuan ton per tahun.

\section{3) Stok beras}

Stok beras adalah tersedianya beras dari hasil produksi dalam negeri dan cadangan beras nasional serta impor apabila kedua sumber utama tidak dapat memenuhi kebutuhan dalam satuan ton per tahun.

4) Harga Beras Domestik

Harga beras domestik adalah harga pembelian konsumen beras dalam satuan rupiah per kilogram per tahun.

5) Harga Beras Internasional

Harga beras internasional adalah harga beras di pasar dunia dalam satuan US\$ per ton per tahun.

6) Nilai tukar rupiah terhadap dollar Amerika

Nilai tukar rupiah terhadap dollar Amerika adalah besaran nilai rupiah per 1 dollar Amerika per tahun.

\section{HASIL DAN PEMBAHASAN}

Identifikasi Faktor-Faktor yang Mempengaruhi Impor Beras diIndonesia

Persamaan regresi yang digunakan dalam penelitian ini menggambarkan perilaku impor beras di Indonesia dengan menggunakan analisis regresi linier berganda pada program SPSS versi 21. Data yang digunakan dalam penelitian ini adalah deret waktu (time series) dari tahun 1994-2013. Pada model dilakukan serangkaian pengujian baik secara statistik maupun secara ekonometrik. 
Setelah itu, pembahasan ekonomi diikutsertakan guna menganalisis hasil estimasi dengan keadaan yang sebenarnya. Pada uji statistik, data hasil estimasi dianalisis menggunakan uji F (uji simultan), uji-t (uji parsial), dan uji koefisien determinasi (R2). Pada uji ekonometrik di uji dengan menggunakan uji asumsi klasik, yaitu uji normalitas, heteroskedastisitas, uji multikolinieritas, dan uji autokorelasi.

Berdasarkan hasil perhitungan menggunakan alat bantu SPSS 21, hasil yang diperoleh untuk perhitungan regresi linier berganda dari faktor-faktor yang mempengaruhi impor beras di Indonesia disajikan pada tabel 5.

Tabel 5. Hasil Regresi Faktor-Faktor yang Mempengaruhi Impor Beras di Indonesia

\begin{tabular}{|l|l|l|l|l|l|}
\hline \multirow{2}{*}{ Model } & \multicolumn{2}{|l|}{$\begin{array}{l}\text { Unstandardized } \\
\text { Coefficients }\end{array}$} & $\begin{array}{l}\text { Standardized } \\
\text { Coefficients }\end{array}$ & T & \multirow{2}{*}{ Sig. } \\
\cline { 2 - 6 } & $\mathbf{B}$ & Std. Error & Beta & & \\
\hline Constanta & 117.084 & 91.359 & & 1.282 & .222 \\
\hline Produksi & -20.047 & 4.411 & -2.284 & -4.545 & .001 \\
\hline Konsumsi & 15.237 & 6.081 & .650 & 2.506 & .026 \\
\hline Stok & .598 & .210 & .653 & 2.842 & .014 \\
\hline HBD & 3.826 & .715 & 2.734 & 5.348 & .000 \\
\hline HBI & .183 & .059 & .700 & 3.118 & .008 \\
\hline Kurs & -3.785 & .667 & -1.857 & -5.671 & .000 \\
\hline
\end{tabular}

Sumber: Data sekunder (diolah)

Berdasarkan hasil regresi pada tabel 5, dapat diketahui persamaan regresi sebagai berikut:

$\mathrm{Y}=117,084+(-20,047) \mathrm{X} 1+15,237$

$\mathrm{X} 2+0,598 \mathrm{X} 3+3,826 \mathrm{X} 4+0,183$

$\mathrm{X} 5+(-3,785) \mathrm{X} 6$

Di mana:

$\mathrm{Y} \quad=$ Impor Beras di Indonesia

$\mathrm{X} 1=$ Produksi Beras

$\mathrm{X} 2 \quad=$ Konsumsi Beras

$\mathrm{X} 3=$ Stok Beras

$\mathrm{X} 4=$ Harga Beras Domestik

X5 = Harga Beras Internasional

X6 = Nilai Tukar Rupiah

Terhadap Dollar Amerika

Berdasarkan hasil persamaan regresi yang diperoleh, maka model regresi tersebut dapat diinterpretasikan sebagai berikut:
1) Nilai koefisien konstanta (a) sebesar 117,084. Nilai ini memiliki arti bahwa apabila seluruh variabel bebas (produksi beras, konsumsi beras, stok beras, harga beras domestik, harga beras internasional, dan nilai tukar Rupiah terhadap Dollar Amerika) bernilai nol, maka besarnya variabel terikat (impor beras) mempunyai nilai sebesar 117,084 .

2) Koefisien produksi beras (X1) bernilai $(-20,047)$. Artinya apabila nilai X1 mengalami kenaikan sebesar 1 ton, maka impor beras Indonesia akan menurun sebesar 20,047 ton dengan asumsi variabel bebas lainnya bersifat tetap. 
3) Koefisien konsumsi beras (X2) bernilai 15,237 . Artinya apabila nilai X2 mengalami kenaikan sebesar 1 ton, maka impor beras Indonesia akan meningkat sebesar 15,237 ton dengan asumsi variabel bebas lainnya bersifat tetap.

4) Koefisien stok beras (X3) bernilai 0,598. Artinya apabila nilai X3 mengalami kenaikan sebesar 1 ton, maka impor beras di Indonesia akan mengalami peningkatan sebesar 0,598 ton dengan asumsi variabel bebas lainnya bersifat tetap.

5) Koefisien harga beras domestik (X4) bernilai 3,826. Artinya apabila nilai X4 mengalami kenaikan sebesar 1 rupiah per $\mathrm{kg}$, maka impor beras Indonesia akan meningkat sebesar 3,826 ton dengan asumsi variabel bebas lainnya bersifat tetap.

6) Koefisien harga beras internasional (X5) bernilai 0,183. Artinya apabila nilai X5 mengalami kenaikan sebesar 1 US\$ per kg, maka impor beras Indonesia akan meningkat sebesar 0,183 ton dengan asumsi variabel bebas lainnya bersifat tetap.

7) Koefisien nilai tukar Rupiah terhadap Dollar Amerika (X6) bernilai $(-3,785)$. Artinya apabila nilai X6 mengalami kenaikan sebesar 1 rupiah per US\$, maka impor beras Indonesia akan menurun sebesar 3,785 ton dengan asumsi variabel bebas lainnya bersifat tetap.

Dalam penelitian ini dapat diketahui bahwa koefisien positif artinya apabila faktor yang mempengaruhi impor beras di Indonesia mengalami kenaikan, maka impor beras pun akan mengalami kenaikan. Sedangkan koefisien negatif artinya apabila variabel bebas yang mempengaruhi impor beras di Indonesia mengalami kenaikan, maka impor beras di Indonesia akan mengalami penurunan. Adapun faktor-faktor yang memiliki hubungan positif adalah konsumsi beras, stok beras, harga beras domestik, dan harga beras internasional. Sedangkan Faktor-faktor yang memiliki hubungan negatif dengan impor beras di Indonesia adalah produksi beras dan nilai tukar Rupiah terhadap Dollar Amerika.

\section{Hasil Uji Asumsi Klasik}

Hasil Uji Normalitas

Hasil uji normalitas terlihat dalam grafik Normal P-P Plot of Regression Standardized Residual dapat dilihat pada gambar 6 .

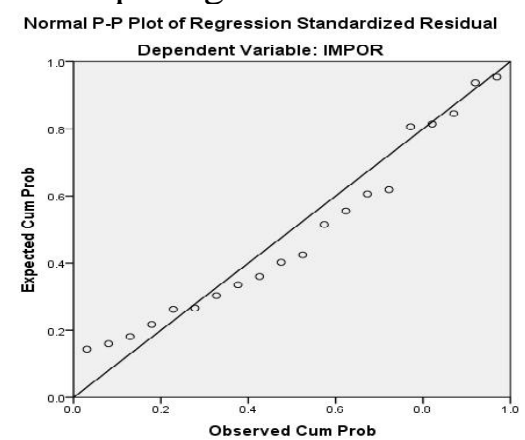

Gambar 6. Normal P-Plot of Regression Standardized Residual Sumber: Data sekunder (diolah) Gambar 6 menunjukkan bawah pada grafik Normal P-P Plot of Regression Standardized Residual, titik-titiknya menyebar tidak jauh pada sumbu diagonal $\mathrm{p}^{-}$plot sehingga dapat dikatakan data terdistribusi secara normal sehingga memenuhi asumsi normalitas. Salah satu cara termudah untuk melihat normalitas residual adalah dengan melihat Normal Probability Plot yang membandingkan distribusi kumulatif dari distribusi normal. Berikut adalah uji normalitas menggunakan uji 
kolmogrov Smirnov dapat dilihat pada tabel 6 .

Tabel 6. Hasil Uji Kolmogrov Smirnov

\begin{tabular}{|l|l|}
\hline & $\begin{array}{l}\text { Unstandardized } \\
\text { Residual }\end{array}$ \\
\hline $\mathrm{N}$ & 20 \\
\hline $\begin{array}{l}\text { Asymp. Sig.(2- } \\
\text { tailed) }\end{array}$ & .822 \\
\hline
\end{tabular}

Sumber: Data sekunder (diolah)

Berdasarkan tabel 6, uji Kolmogrov Smirnov memiliki nilai signifikan sebesar 0,822 lebih besar dari 0,05. Dari hasil ini menunjukkan bahwa residual terdistribusi secara normal.

\section{Hasil Uji Heteroskedastisitas}

Hasil uji heteroskedastisitas dalam penelitian ini disajikan pada gambar 7 .

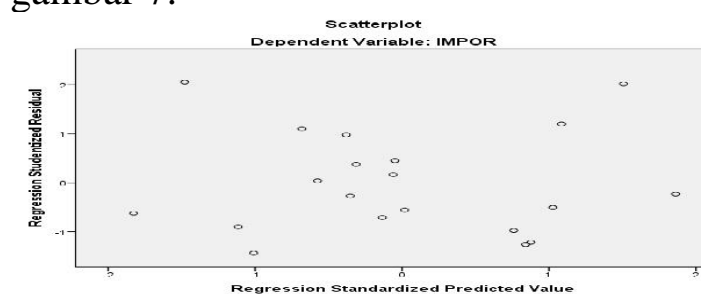

Gambar 7. Scatterplot

Sumber: Data sekunder (diolah)

Gambar 7 menunjukkan pada diagram scatterplot terlihat bahwa titik-titik menyebar secara acak, serta tersebar diatas maupun dibawah angka 0 pada sumbu $Y$ sehingga dapat disimpulkan bahwa tidak terdapat gejala heteroskedastisitas pada model regresi yang digunakan.

Tampilan hasil uji glejser dalam penelitian ini dapat dilihat pada tabel 7.

Tabel 7. Hasil Uji Glejser

\begin{tabular}{|l|l|l|}
\hline $\begin{array}{l}\text { Variabel } \\
\text { Independen }\end{array}$ & $\mathrm{t}$ & Sig. \\
\hline Produksi & .032 & .975 \\
\hline Konsumsi & -1.118 & .284 \\
\hline Stok & -.976 & .347 \\
\hline
\end{tabular}

\begin{tabular}{|l|l|l|}
\hline $\begin{array}{l}\text { Harga Beras } \\
\text { Domestik }\end{array}$ & .638 & .535 \\
\hline $\begin{array}{l}\text { Harga Beras } \\
\text { Internasional }\end{array}$ & .407 & .691 \\
\hline Kurs & .084 & .932 \\
\hline
\end{tabular}

bahwa variabel produksi, konsumsi, stok beras, harga beras domestik, harga beras internasional, dan kurs memiliki nilai signifikan 0,975 ; 0,$284 ; 0,347 ; 0,535 ; 0,691 ; 0,932$ yang kesemuanya lebih besar dari 0,05 . Artinya bahwa tidak terdapat masalah heteroskedastisitas dalam model regresi ini, dengan kata lain semua variabel independen yang terdapat dalam model ini memiliki sebaran varian yang sama/homogen.

\section{Hasil Uji Multikolinieritas}

Hasil uji multikolinieritas penelitian ini disajikan pada tabel 8 .

Tabel 8. Hasil Uji Multikolinieritas

\begin{tabular}{|l|l|l|}
\hline Variabel & \multicolumn{2}{|l|}{ Collinierity Statistics } \\
\cline { 2 - 3 } independen & Tolerance & VIF \\
\hline Produksi & .565 & 1.770 \\
Konsumsi & .598 & 1.673 \\
Stok & .853 & 1.172 \\
Harga Beras & .848 & 1.180 \\
Domestik & & \\
Harga Beras & .794 & 1.259 \\
Internasional & & \\
Kurs & .812 & 1.232 \\
\hline
\end{tabular}

Sumber: Data sekunder (diolah)

Tabel 8 menunjukkan bahwa nilai VIF untuk produksi beras, konsumsi beras, stok beras, harga beras domestik, harga beras internasional, dan kurs memiliki nilai VIF $<10$ dan nilai tolerance lebih dari 0,10. Dapat disimpulkan bahwa 
model dalam regresi tidak terdapat masalah multikolinieritas.

\section{Hasil Uji Autokorelasi}

Hasil uji autokorelasi penelitian ini disajikan pada tabel 9. Tabel 9. Hasil Uji Durbin-Watson
Sumber: Data sekunder (diolah)

Berdasarkan tabel 10 nilai signifikansi pada uji run test adalah sebesar 0,491 lebih besar dari 0,05. Hal tersebut menunjukkan bahwa tidak terjadi gangguan autokorelasi \begin{tabular}{|l|l|l|l|l|l|}
\hline $\begin{array}{l}\text { Mo } \\
\text { del }\end{array}$ & $\mathrm{R}$ & $\begin{array}{l}\text { RSquar } \\
\mathrm{e}\end{array}$ & $\begin{array}{l}\text { Adjusted } \\
\mathrm{R} \\
\text { Square }\end{array}$ & $\begin{array}{l}\text { Std. Error } \\
\text { of } \\
\text { theEstimat } \\
\mathrm{e}\end{array}$ & $\begin{array}{l}\text { Durbipada penelitian ini. Ghozali } \\
\text { Watsq2011:121) mengemukakan jika nilai } \\
\text { signifikansi dari run test yang } \\
\text { dihasilkan lebih dari 0,05 maka tidak }\end{array}$ \\
\hline 1 & $.940^{\mathrm{a}}$ & .883 & .829 & .45419 & $\begin{array}{r}2.58 \\
\text { terjadi masalah autokorelasi sehingga } \\
\text { model regresi layak digunakan. }\end{array}$ \\
\hline
\end{tabular}

Sumber: Data sekunder (diolah)

Tabel 9 menunjukkan bahwa nilai Durbin-Watson (D-W) sebesar 2,587. Nilai ini akan dibandingkan dengan nilai Durbin-Watson (D-W) tabel dengan signifikansi 0,05. Jumlah data (n) adalah 20 dan jumlah variabel independennya $(\mathrm{k})$ adalah 6 , diperoleh nilai dL sebesar 0,6915, nilai dU sebesar 2,1619, nilai 4-dL sebesar 3,3085 dan 4-dU sebesar 1,8381. Nilai Durbin-Watson yang dihasilkan pada penelitian ini mendekati angka 2, maka dapat disimpulkan bahwa data tidak mengalami gejala autokorelasi.

Hasil run test penelitian ini dapat dilihat pada tabel 10 .

Tabel 10. Hasil Uji Run Test

\begin{tabular}{|l|l|}
\hline & $\begin{array}{l}\text { Unstandardized } \\
\text { Residual }\end{array}$ \\
\hline Test Valuea & -.09930 \\
\hline $\begin{array}{l}\text { Cases }<\text { Test } \\
\text { Value }\end{array}$ & 10 \\
\hline $\begin{array}{l}\text { Cases > Test } \\
\text { Value }\end{array}$ & 10 \\
\hline Total Cases & 20 \\
\hline Number of Runs & 13 \\
\hline Z & .689 \\
\hline $\begin{array}{l}\text { Asymp. Sig. (2- } \\
\text { tailed) }\end{array}$ & .491 \\
\hline
\end{tabular}

\section{Hasil Uji Koefisien Determinasi}

Koefisien determniasi pada penelitian ini ditampilkan pada tabel 11.

Tabel 11. Hasil Uji Adjusted R Square

\begin{tabular}{|l|l|l|l|l|}
\hline $\begin{array}{l}\text { Mod } \\
\text { el }\end{array}$ & R & $\begin{array}{l}\text { R } \\
\text { Squa } \\
\text { re }\end{array}$ & $\begin{array}{l}\text { Adjust } \\
\text { ed } \\
\mathrm{R} \\
\text { Square }\end{array}$ & $\begin{array}{l}\text { Std. } \\
\text { Error } \\
\text { of the } \\
\text { Estima } \\
\text { te }\end{array}$ \\
\hline 1 & $\begin{array}{l}.940 \\
\mathrm{a}\end{array}$ & .883 & .829 & .45419 \\
\hline
\end{tabular}

Sumber: Data sekunder (diolah)

Tabel 11 menunjukkan nilai koefisien determinasi sebesar 0,829. Artinya variabel independen yaitu produksi beras, konsumsi beras, stok beras, harga beras domestik, harga beras internasional, dan nilai tukar Rupiah terhadap Dollar Amerika mampu menjelaskan variabel dependennya yaitu impor beras sebesar 82,9\% sisanya sebesar $17,1 \%$ dijelaskan oleh variabel lain yang tidak dimasukkan dalam model penelitian ini

\section{Hasil Uji F (Uji Simultan)}

Hasil pengolahan uji $\mathrm{F}$ pada penelitian ini disajikan pada tabel 12 . Tabel 12. Hasil uji F (Uji Simultan) Analisis Faktor-Faktor Yang 
Mempengaruhi Impor Beras di tersebut menunjukkan bahwa $\mathrm{F}_{\text {hitung }}=$ Indonesia

\begin{tabular}{|l|l|l|l|l|l|} 
Model & $\begin{array}{l}\text { Sum } \\
\text { of } \\
\text { Squares }\end{array}$ & df & $\begin{array}{l}\text { Mean } \\
\text { Square }\end{array}$ & F & Sig. \\
Regression & 20.204 & 6 & 3.367 & 16.324 & .000 \\
Residual & 2.682 & 13 & .206 & & \\
Total & 22.886 & 19 & & & \\
\hline
\end{tabular}

Sumber: Data sekunder (diolah)

Hasil uji $\mathrm{F}$ yang terlihat pada

tabel 13 menunjukkan pada tingkat signifikan $5 \%$, df1=6 dan df2=13, maka di dapat nilai $\mathrm{F}_{\text {hitung }}$ (Fstatistic) sebesar 16.324. Nilai

16.324 lebih besar dari $\mathrm{F}_{\text {tabel }}$ yaitu

2,922 dengan nilai probabilitas 0,000

Sig. yang berarti dibawah nilai signifikansi 0,05. Dapat disimpulkan $\mathrm{H}_{0}$ ditolak dan $\mathrm{H}_{\mathrm{a}}$ diterima yang oberarti variabel independen yaitu produksi, konsumsi, stok, harga beras domestik, harga beras internasional, dan nilai tukar rupiah terhadap dollar Amerika secara simultan (bersamasama) memiliki pengaruh terhadap impor beras di Indonesia.

\section{Hasil Uji t (Uji Parsial)}

Hasil pengolahan uji $t$ pada penelitian ini disajikan pada tabel 13

Tabel 13. Hasil Uji t (Uji Parsial) Analisis Faktor-Faktor Yang Mempengaruhi Impor Beras di Indonesia

\begin{tabular}{|c|c|c|c|c|c|}
\hline \multirow[b]{2}{*}{ Model } & \multicolumn{2}{|c|}{ Unstandardized Coefficient } & \multicolumn{2}{|c|}{$\begin{array}{l}\text { Standardized } \\
\text { Coefficients }\end{array}$} & \multirow[b]{2}{*}{ Sig. } \\
\hline & $\mathrm{B}$ & Std. Error & Beta & t & \\
\hline Constanta & 117.084 & 91.359 & & 1.282 & .222 \\
\hline Produksi & -20.047 & 4.411 & -2.284 & -4.545 & .001 \\
\hline Konsumsi & 15.237 & 6.081 & .650 & 2.506 & .026 \\
\hline Stok & .598 & .210 & .653 & 2.842 & .014 \\
\hline HBD & 3.826 & .715 & 2.734 & 5.348 & .000 \\
\hline HBI & .183 & .059 & .700 & 3.118 & .008 \\
\hline Kurs & -3.785 & .667 & -1.857 & -5.671 & .000 \\
\hline
\end{tabular}

Sumber: Data

Hasil uji t yang terlihat pada tabel 13 menunjukkan pada tingkat signifikansi $5 \%$ dan nilai $\mathrm{df}=12$, diperoleh $\mathrm{t}$ tabel 1,7613.

1) Tabel 13 dapat diketahui variabel produksi (X1) sebesar -4,545. Nilai thitung tersebut berada di atas $-t_{\text {tabel }}$ sebesar -1,7613. Maka - $t_{\text {hitung }}>$-ttabel, $\mathrm{HO}$ ditolak dan $\mathrm{H}_{\mathrm{a}}$ diterima. Angka signifikan untuk variabel produksi sebesar 0,001, Sig. $<0,05$ maka $\mathrm{H}_{0}$ ditolak dan $\mathrm{H}_{\mathrm{a}}$ diterima. Hal tersebut berarti bahwa variabel produksi memiliki pengaruh negative dan
Sekunder

(diolah) signifikan terhadap impor beras di Indonesia.

2) Tabel 13 menunjukkan nilai thitung untuk variabel konsumsi $\left(\mathrm{X}_{2}\right)$ sebesar 2,506. Nilai t tersebut berasa di atas ttabel sebesar 1,7613 (thitung > ttabel), maka $\mathrm{H}_{0}$ ditolak dan $\mathrm{H}_{\mathrm{a}}$ diterima. Angka signifikansi untuk variable konsumsi sebesar 0,026 lebih kecil dari 0,05 maka $\mathrm{H}_{0}$ ditolak dan $\mathrm{H}_{\mathrm{a}}$ diterima. Dapat disimpulkan bahwa ada pengaruh positif dan signifikan antara konsumsi terhadap impor beras di Indonesia. 
3) Tabel 13 menunjukkan nilai untuk thitung variabel stok $\left(\mathrm{X}_{3}\right)$ sebesar 2,842 .

Nilai tersebut berada di atas ttabel sebesar 1,7613 ( $t_{\text {hitung }}>t_{\text {tabel }}$ ), maka $\mathrm{H}_{0}$ ditolak dan $\mathrm{H}_{\mathrm{a}}$ diterima. Angka signifikansi untuk variabel stok sebesar 0,014 lebih kecil dari 0,05. Sehingga dapat disimpulkan bahwa stok beras berpengaruh positif dan signifikan terhadap impor beras di Indonesia.

4) Tabel 13 menunjukkan nilai untuk $t_{\text {hitung variabel harga beras domestik }}$ $\left(\mathrm{X}_{4}\right)$ sebesar 5,348. Nilai tersebut berada di atas ttabel sebesar 1,7613 ( $\left.t_{\text {hitung }}>\mathrm{t}_{\text {tabel }}\right)$, maka $\mathrm{H}_{0}$ ditolak dan $\mathrm{H}_{\mathrm{a}}$ diterima. Angka signifikansi untuk koefisien harga beras domestik sebesar 0,000 lebih kecil dari 0,05. Sehingga dapat disimpulkan bahwa harga beras domestik berpengaruh positif dan signifikan terhadap impor beras di Indonesia.

5) Tabel 13 menunjukkan nilai untuk thitung variabel harga beras internasional $\left(\mathrm{X}_{5}\right)$ sebesar 3,118. Nilai tersebut berada di atas ttabel sebesar 1,7613 (thitung > ttabel), maka $\mathrm{H}_{0}$ ditolak dan $\mathrm{H}_{\mathrm{a}}$ diterima. Angka signifikansi untuk koefisien harga beras internasional sebesar $0,008<0,05$. Sehingga dapat disimpulkan bahwa harga beras internasional berpengaruh secara positif dan signifikan terhadap impor beras di Indonesia.

6) Tabel 13 menunjukkan nilai untuk -thitung variabel kurs $\left(\mathrm{X}_{6}\right)$ sebesar 5,671. Nilai tersebut berada di atas ttabel yaitu $-1,7613$ (-t hitung $\left.>-t_{\text {tabel }}\right)$, maka $\mathrm{H}_{0}$ ditolak dan $\mathrm{H}_{\mathrm{a}}$ diterima. Angka signifikansi untuk variabel kurs sebesar 0,000 lebih kecil dari
0,05. Sehingga dapat disimpulkan bahwa variabel kurs memiliki pengaruh negatif dan signifikan terhadap impor beras di Indonesia.

Uji $t$ pada dasarnya menunjukan seberapa jauh pengaruh variabel independen secara individual dalam menerangkan variasi variable dependen (Ghozali, 2011:98). Kriteria yangdipakai untuk membuat keputusan terhadap hasil uji hipotesis adalah berdasarkan tingkat signifikans sebesar 0,05yang merupakan probabilitas kesalahan 5\%.

T-test dilakukan dengan membandingkan T-hitung dengan $\mathrm{T}$ tabel. Nilai dari uji T-test dapat dilihat dari $\mathrm{T}$ hitung dibandingkan dengan $\mathrm{T}$ tabel sebagai berikut:

1) Jika tHitung>-tTabel atau tHitung>tTabel, maka $\mathrm{H}_{0}$ ditolak, $\mathrm{H}_{\mathrm{a}}$ diterima.

2) Jika tHitung $\leq$-tTabel atau tHitung $\leq \mathrm{t}$ Tabel, maka $\mathrm{H}_{0}$ diterima, Ha ditolak.

Sedangkan signifikansi di uji melalui probabilitas dengan kriteria:

1) Jika nilai sig. $<0,05$ maka hipotesis alternative (Ha) diterima dan $\left(\mathrm{H}_{0}\right)$ ditolak, artinya bahwa variable bebassecara signifikan berpengaruh terhadap variabel terikat.

2) Jika nilai sig. $>0,05$ maka hipotesis alternative $(\mathrm{Ha})$ ditolak dan $\left(\mathrm{H}_{0}\right)$ diterima, artinya bahwa variable bebas tidak berpengaruh secara signifikan terhadap variabel terikat.

Faktor-Faktor

yang

Mempengaruhi Impor Beras di Indonesia

Pembahasan pengaruh faktorfaktor terhadap impor beras di Indonesia dijelaskan sebagai berikut:

\section{Produksi Beras (X1)}

Hasil olah data variabel produksi beras berdasarkan regresi 
dan hasil uji $\mathrm{T}$ disajikan pada tabel 14.

\begin{tabular}{|l|l|l|l|}
\hline Variabel & $\begin{array}{l}\text { Hasil } \\
\text { Regresi }\end{array}$ & $\begin{array}{l}\text { Hasil } \\
\text { Uji T }\end{array}$ & $\begin{array}{l}\text { Batas } \\
\text { Uji T }\end{array}$ \\
\hline $\begin{array}{l}\text { Produksi } \\
\text { Beras }\end{array}$ & -20.047 & - & - \\
& 4.545 & 1.7613 \\
\hline
\end{tabular}

Variabel produksi beras memiliki koefisien regresi sebesar 20.047 yang berarti bahwa peningkatan produksi sebesar 1 ton maka akan menurunkan impor beras di Indonesia sebesar 20,047\%. Nilai t hitung > t tabel, yaitu $-4,545>$ 1,7613. Hasil yang didapatkan menunjukkan bahwa H01 ditolak dan Hal diterima. Hal ini berarti variabel produksi beras memiliki pengaruh signifikan terhadap impor beras di Indonesia.

\section{Konsumsi Beras (X2)}

Hasil olah data variabel konsumsi beras berdasarkan regresi dan hasil uji $\mathrm{T}$ disajikan pada tabel 15.

Tabel 15. Hasil Olah Data Variabel Konsumsi Beras

\begin{tabular}{|l|l|l|l|}
\hline Variabel & $\begin{array}{l}\text { Hasil } \\
\text { Regres } \\
\text { i }\end{array}$ & $\begin{array}{l}\text { Hasil } \\
\text { Uji T }\end{array}$ & $\begin{array}{l}\text { Batas } \\
\text { Uji T }\end{array}$ \\
\hline $\begin{array}{l}\text { Konsums } \\
\text { i beras }\end{array}$ & 15.237 & $\begin{array}{l}2.50 \\
6\end{array}$ & $\begin{array}{l}1.761 \\
3\end{array}$ \\
\hline
\end{tabular}

Variabel konsumsi beras memiliki koefisien regresi sebesar 15,237 yang berarti bahwa peningkatan konsumsi beras sebesar 1 ton akan meningkatkan impor beras di Indonesia sebesar $15,237 \%$. Nilai t hitung $>\mathrm{t}$ tabel, yaitu 2,506 >1,7613. Hasil yang didapatkan menunjukkan bahwa $\mathrm{H}_{02}$ ditolak dan $\mathrm{H}_{\mathrm{a} 2}$ diterima. Hal ini berarti variabel konsumsi beras memiliki pengaruh signifikan terhadap impor beras di Indonesia.

\section{Stok Beras (X3)}

Hasil olah data variabel stok beras berdasarkan regresi dan hasil uji $\mathrm{T}$ disajikan pada tabel 16 .

Tabel 16. Hasil Olah Data Variabel Stok Beras

\begin{tabular}{|l|l|l|l|}
\hline Variabel & $\begin{array}{l}\text { Hasil } \\
\text { Regresi }\end{array}$ & $\begin{array}{l}\text { Hasil } \\
\text { Uji T }\end{array}$ & $\begin{array}{l}\text { Batas } \\
\text { Uji T }\end{array}$ \\
\hline $\begin{array}{l}\text { Stok } \\
\text { beras }\end{array}$ & .598 & 2.842 & 1.7613 \\
\hline
\end{tabular}

Variabel stok beras memiliki koefisien regresi sebesar 0,598 yang berarti bahwa peningkatan stok beras sebesar 1 ton akan meningkatkan impor beras di Indonesia sebesar $0,598 \%$. Hubungan positif tersebut menggambarkan bahwa stok beras merespon terhadap impor beras di Indonesia. Nilai t hitung > t tabel, yaitu2,842 > 1,7613. Hasil yang didapatkan menunjukkan bahwa $\mathrm{H}_{03}$ ditolak dan $\mathrm{H}_{\mathrm{a} 3}$ diterima. Hal ini berarti variabel stok beras memiliki pengaruh signifikan terhadap impor beras di Indonesia.

\section{Harga Beras Domestik (X4)}

Hasil olah data variabel harga beras domestik berdasarkan regresi dan hasil uji $\mathrm{T}$ disajikan pada tabel 17.

Tabel 17. Hasil Olah Data Variabel Harga Beras Domestik

\begin{tabular}{|l|l|l|l|}
\hline Variabel & $\begin{array}{l}\text { Hasil } \\
\text { Regresi }\end{array}$ & $\begin{array}{l}\text { Hasil } \\
\text { Uji T }\end{array}$ & $\begin{array}{l}\text { Batas } \\
\text { Uji T }\end{array}$ \\
\hline $\begin{array}{l}\text { Harga } \\
\text { beras } \\
\text { domestik }\end{array}$ & 3.826 & 5.348 & 1.7613 \\
\hline
\end{tabular}

Variabel harga beras domestik memiliki koefisien regresi sebesar 3,826 yang berarti bahwa 
peningkatan harga beras domestik sebesar 1 rupiah akan meningkatkan impor beras di Indonesia sebesar $3,826 \%$. Nilai t hitung $>\mathrm{t}$ tabel, yaitu $5,348>1,7613$. Hasil yang didapatkan menunjukkan bahwa $\mathrm{H}_{04}$ ditolak dan $\mathrm{H}_{\mathrm{a} 4}$ diterima. Hal ini berarti variabel harga beras domestik memiliki pengaruh signifikan terhadap impor beras di Indonesia.

\section{Harga Beras Internasional (X5)}

Hasil olah data variabel harga beras internasional berdasarkan regresi dan hasil uji $\mathrm{T}$ disajikan pada tabel 18.

Tabel 18. Hasil Olah Data Variabel Harga Beras Internasional

\begin{tabular}{|l|l|l|l|}
\hline Variabel & $\begin{array}{l}\text { Hasil } \\
\text { Regresi }\end{array}$ & $\begin{array}{l}\text { Hasil } \\
\text { Uji T }\end{array}$ & $\begin{array}{l}\text { Batas } \\
\text { Uji T }\end{array}$ \\
\hline $\begin{array}{l}\text { Harga beras } \\
\text { internasional }\end{array}$ & 0.183 & 3.118 & 1.7613 \\
\hline
\end{tabular}

\begin{tabular}{|l|l|l|l|}
\hline & Regresi & Uji T & Uji T \\
\hline Kurs & -3.785 & - & - \\
& & 5.671 & 1.7613 \\
\hline
\end{tabular}

Variabel nilai tukar rupiah terhadap dollar Amerika memiliki koefisien regresi sebesar $-3,785$ yang berarti bahwa peningkatan kurs sebesar 1 rupiah per US\$ akan menurunkan impor beras di Indonesia sebesar 3,785\%. Nilai t hitung > $\mathrm{t}$ tabel, yaitu $-5,671>-1,7613$. Hasil yang didapatkan menunjukkan bahwa H06 ditolak dan Ha6 diterima. Hal ini berarti variabel nilai tukar rupiah terhadap dollar Amerika memiliki pengaruh signifikan terhadap impor beras di Indonesia.

\section{KESIMPULAN}

Berdasarkan analisis dan

Variabel harga beras internasional memiliki koefisien regresi sebesar 0,183 yang berarti bahwa peningkatan harga beras internasional sebesar 1 US\$ akan meningkatkan impor beras di Indonesia sebesar $0,183 \%$. Nilai $\mathrm{t}$ hitung $>\mathrm{t}$ tabel, yaitu 3,118 > 1,7613. Hasil yang didapatkan menunjukkan bahwa H05 ditolak dan Ha5 diterima. Hal ini berarti variabel harga beras internasional memiliki pengaruh signifikan terhadap impor beras di Indonesia.

\section{Nilai Tukar Rupiah Terhadap Dollar Amerika (X6)}

Hasil olah data variabel nilai tukar rupiah terhadap dollar Amerika berdasarkan regresi dan hasil uji $\mathrm{T}$ disajikan pada tabel 19.

Tabel 19. Hasil Olah Data Variabel Kurs

\begin{tabular}{|l|l|l|l|}
\hline Variabel & Hasil & Hasil & Batas \\
\hline
\end{tabular}

pembahasan hasil penelitian dengan menggunakan uji regresi linier berganda mengenai analisis faktorfaktor yang mempengaruhi impor beras di Indonesia, maka dapat disimpulkan sebagai berikut:

1. Hasil penelitian menunjukkan bahwa variabel produksi beras, konsumsi beras, stok beras, harga beras domestik, harga beras internasional, dan nilai tukar rupiah terhadap dollar Amerika secara bersama-sama memiliki pengaruh signifikan terhadap impor beras di Indonesia.

2. Hasil penelitian menyatakan bahwa variabel konsumsi beras, stok beras, harga beras domestik, dan harga beras internasional memiliki pengaruh positif dan signifikan terhadap impor beras di Indonesia dengan tingkat kepercayaan $\alpha$ 95\%. Sedangkan 
variabel produksi beras dan nilai tukar rupiah terhadap dollar Amerika memiliki pengaruh negative dan signifikan terhadap impor beras di Indonesia dengan tingkat kepercayaan $\alpha 95 \%$.

\section{DAFTAR PUSTAKA}

Ali, Fachri, dkk. Beras, Koperasi dan Politik Orde Baru. Bustanil Arifin 70 tahun. Jakarta: Sinar Harapan, 1996.

Arifin, Bustanul. Diagnosis Ekonomi Politik Pangan dan Pertanian. Jakarta: PT. Raja Grafindo Persada, 2007.

Amang, Beddu. Ekonomi Perberasan, Jagung dan Minyak Sawit. Jakarta: PT. Dharma Karsa Utama, 1993.

Amang, Beddu dan M. Husein Sawit. Kebijakan Beras dan Pangan Nasional: Pelajaran dari Orde Baru dan Era Reformasi. Bogor: Institut Pertanian Bogor, 1999.

Astawan, Made. Sehat Bersaman Aneka Serat Pangan Alami. Solo: TigaSerangkai, 2004.

Aziz, Arif Abdul. Analisis Impor Beras Serta Pengaruhnya Terhadap Harga Beras Dalam Negeri. [Skripsi]. Institut Pertanian Bogor. Fakultas Pertanian. Program Studi Manajemen Agribisnis. 2006.

Bahasoan, Husen. Analisis Efisiensi Usahatani Padi Sawah Pada Program Pengelolaan
Tanaman Terpadu Di Kabupaten Buru. Agribusiness Journal Vol. 7, no. 2 (Desember 2013): h. 76-143.

Bank Indonesia. Nilai Kurs Tahun 1994 - 2013. www.bi.go.id. Diakses pada tanggal 15 Juli 2014.

Badan Pusat Statistik. Tanaman Pangan. www.bps.go.id. Diakses pada tanggal 7Juni 2014.

- Konsumsi Beras Rumah Tangga. www.bps.go.id. Diakses pada tanggal 1 Juli 2014.

Beacukai. Pengertian Impor. www.beacukai.go.id. Diakses pada tanggal 17 Maret 2014.

Christianto, Edward. Faktor Yang Mempengaruhi Volume Impor Beras DiIndonesia. JIBEKA Jurnal Vol. 7, no.2 (Agustus 2013): h. $38-43$.

Departemen Pertanian. Outlook Komoditas Pertanian Tanaman Pangan. Jakarta: Departemen Pertanian, 2012.

Firdaus, Muhammad, dkk. Swasembada Beras Dari Masa Ke Masa Telaah Efektivitas Kebijakan dan Perumusan Strategi Nasional. Bandung: IPB Press, 2008.

Ghozali, Imam. Aplikasi Analisis Multivariate Dengan Program IBM SPSS 19.Semarang: Badan Penerbit Universitas Diponegoro, 2011. 
Gonarsyah, Isang. Pembangunan Tanaman Pangan Dan Hortikultura: Perspektif Ekonomi Politik. Dalam R. Wibowo (Ed.). Pertanian dan Pangan Bunga Rampai Pemikiran Menuju Ketahanan Pangan. Jakarta: Pustaka Sinar Harapan, 2000.

Hady, Hamdy. Ekonomi Internasional Teori dan Kebijakan Keuangan Internasional. Jakarta: Ghalia Indonesia, 2004.

Hapsari, Nungsri Tri. Analisis Faktor-Faktor Yang Mempengaruhi Impor Gula Indonesia Periode 1983-2006. [Skripsi]. Institut Pertanian Bogor. Fakultas Ekonomi Dan Manajemen. Departemen Ilmu Ekonomi. 2007.

Hasyim.

Teori

Permintaan

Dalam

Islam.

https://theoryiaslmhasyim.word press.com/2013/04/26/teoripermintaan- dalam-islam/. Diakses pada tanggal 17 November 2014.

Hessie, Retha. Analisis Produksi Dan Konsumsi Beras Dalam Negeri Serta Implikasinya Terhadap Swasembada Beras Di Indonesia. [Skripsi]. Institut Pertanian Bogor. Fakultas Ekonomi Dan Manajemen. Departemen Ekonomi Sumberdaya Dan Lingkungan. 2009.

Karim, Adiwarman A. Ekonomi Mikro Islami. Jakarta: PT. Raja Grafindo Persada,2008.
Lipsey, R. G. dkk. Wasana dan Kirbrandoko (penerjemah). Pengantar Mikroekonomi. Edisi Kedelapan. Jakarta: Erlangga, 1997.

Litbang. Pengelolaan Tanaman Terpadu (PTT) Padi Sawah. Jakarta: DepartemenPertanian, 2011.

\begin{tabular}{lrr} 
Arah & Prospek dan \\
Agribisnis & Pengembangan \\
http://www.litbang.pertanian.go \\
\hline .id/special/komoditas/files/0104 \\
-PADI.pdf. Diakses pada \\
tanggal 15 Desember 2014.
\end{tabular}

Mankiw, N.Gregory, dkk. Pengantar Ekonomi Makro. Jakarta: Salemba Empat,2013.

. Pengantar Ekonomi Mikro. Jakarta: Salemba Empat,2013.

Masyhuri. Ekonomi Mikro. Malang: UIN-Malang Press, 2007. Nazir, Moh. Metode Penelitian. Jakarta: Ghalia, 2011.

Purwono dan Heni Purnamawati. Budidaya 8 Jenis Tanaman Pangan Unggul.Jakarta: Penebar Swadaya, 2007.

Rasahan, Chairil Anwar. Pembangunan Tanaman Pangan dan Hortikultura Pada Awal Abad 21 (Sebuah Pengalaman). Dalam R. Wibowo (Ed.). Pertanian dan Pangan Bunga Rampai Pemikiran Menuju Ketahanan Pangan. Jakarta: Pustaka Sinar Harapan, 2000. 
Rungkat, Desiane Maria. Analisis Faktor-Faktor Yang Mempengaruhi Impor Beras Di Sulawesi Utara. [Jurnal]. Manado: Universitas Sam Ratulangi. Fakultas Pertanian. Kementerian Pendidikan Dan Kebudayaan, 2014.

Salvatore, Dominick. Ekonomi Internasional. Edisi Ketiga. Jakarta: Erlangga,1997.

Santoso, Singgih. Statistik Parametrik Konsep dan Aplikasi dengan SPSS. Jakarta: PT. Elex Media Komputindo, 2014.

Sasono, Herman Budi. Manajemen Pelabuhan dan Realisasi Ekspor Impor. Yogyakarta: CV. Andi Offset, 2012.

Sawit, Mohamad Husein. Reformasi Kebijakan Harga Produsen Dan Dampaknya Terhadap Daya Saing Beras. Pengembangan Inovasi Pertanian 4(1): h. 1-13.

Arah Kebijaksanaan Distribusi/Perdagangan Beras Dalam Mendukung Ketahanan Pangan. Dalam R. Wibowo (Ed.). Pertanian dan Pangan Bunga Rampai Pemikiran Menuju Ketahanan Pangan. Jakarta: Pustaka Sinar Harapan, 2000.

Sediaoetama, A. D. Ilmu Gizi untuk Mahasiswa dan Profesi. Jilid I. Jakarta: DianRakyat, 1996.

Sudaryanto, dkk. Arah Kebijakan Distribusi/Perdagangan Beras Dalam Mendukung Ketahanan
Pangan: Aspek Perdagangan Luar Negeri. Dalam R. Wibowo (Ed.). Pertanian dan Pangan Bunga Rampai Pemikiran Menuju Ketahanan Pangan. Jakarta: Pustaka Sinar Harapan, 2000.

Sugiyono. Metode Penelitian Kauntitatif Kualitatif dan $R \& D$. Bandung: Alfabeta,2012.

Sukirno, Sadono. Makroekonomi Teori Pengantar. Edisi Ketiga. Jakarta: PT.RajaGrafindo Persada, 2011.

Pengantar Teori Makroekonomi. Edisi Kedua. Jakarta: PT.RajaGrafindo Persada, 2000.

.Mikro Ekonomi

Teori Pengantar. Jakarta: PT. RajaGrafindoPersada, 2011.

Teguh, Muhammad. Metodologi Penelitian Ekonomi Teori dan Aplikasi. Jakarta: PT. Raja Grafindo Persada, 2005.

Timor, Sholihati Diyan. Analisis Faktor-Faktor Yang Mempengaruhi Produksi Dan Impor Jagung Di Indonesia. [Skripsi]. Institut Pertanian Bogor. Fakultas Ekonomi Dan Manajemen. Departemen Ilmu Ekonomi. 2008.

Wibowo, Rudi. Penyediaan Pangan Dan Permasalahannya. Dalam R. Wibowo (Ed.). Pertanian dan Pangan Bunga Rampai Pemikiran Menuju Ketahanan Pangan. Jakarta: Pustaka Sinar Harapan, 2000. 
Widarjono, Agus. Analisis

Statistika Multivariat Terapan.

Yogyakarta: UPP STIM

YKPN, 2010.

* Alamat Korespondensi:

iskandar.andi@uinjkt.ac.id 
Jurnal Agribisnis, Vol. 11, No. 6, Desember 2017, [ 183 - 201 ]

ISSN : 1979-0058 